\title{
Article \\ Technological Characterization of Almohad Pottery Glazes from SW Mallorca (Balearic Islands, Spain)
}

\author{
Daniel J. Albero Santacreu ${ }^{1, *}$, Jose C. Carvajal López ${ }^{2}$ and Alejandro Ramos Benito ${ }^{3}$ \\ 1 Departament of Historical Sciences and Arts Theory, University of the Balearic Islands, 07122 Palma, Spain \\ 2 School of Archaeology and Ancient History, University of Leicester, Leicester LE1 7RH, UK; \\ jccl2@leicester.ac.uk \\ 3 ArqueoUIB Research Group, University of the Balearic Islands, 07122 Palma, Spain; arbenito@outlook.com \\ * Correspondence: d.albero@uib.es
}

check for updates

Citation: Albero Santacreu, D.J.; Carvajal López, J.C.; Ramos Benito, A. Technological Characterization of Almohad Pottery Glazes from SW Mallorca (Balearic Islands, Spain). Minerals 2022, 12, 106. https:// doi.org/10.3390/min12010106

Academic Editor: Marco Benvenuti

Received: 17 December 2021

Accepted: 13 January 2022

Published: 17 January 2022

Publisher's Note: MDPI stays neutral with regard to jurisdictional claims in published maps and institutional affiliations.

Copyright: () 2022 by the authors. Licensee MDPI, Basel, Switzerland. This article is an open access article distributed under the terms and conditions of the Creative Commons Attribution (CC BY) license (https:// creativecommons.org/licenses/by/ $4.0 /)$.

\begin{abstract}
In this paper, we addressed the chemical composition and main features of a glazed Almohad ceramic assemblage recovered from Puig de Sa Morisca, a rural Islamic site located in southwest Mallorca. The glazes were analyzed by means of scanning electron microscope equipped with energy-dispersive spectrometer (SEM-EDS). The archaeometrical analysis conducted allowed us to characterize the technological choices applied by potters from the end of the 12th century and the beginning of the 13th century. The exclusive use of lead-silica glazes was confirmed, which in some cases was opacified with tin. We also established that some tableware vessels, which were imported to the island, have shown glazes with a particular composition within the analyzed record.
\end{abstract}

Keywords: pottery; Almohad period; Al-Andalus; lead glazes; tin glazes; SEM-EDS

\section{Introduction}

Archaeometric methodologies are relatively recent in the study of Al-Andalus Almohad ceramics, but they have proved excellent for studying distribution networks and vessel technology elsewhere [1-6]. In addition, there are many analytical studies that have addressed the technology of Andalusi ceramic glazes, covering a broad chronology between the 10th and 15th centuries AD [7]. However, such works have been mainly focused on pottery assemblages from southern areas of the Iberian Peninsula associated with the early and late Islamic periods, related to the Nasrid kingdom period of Granada [3,8-11]. Some attention has also been paid to glazed ceramics recovered from archaeological sites located in the northeast of the Iberian Peninsula associated with the Taifa period (12th century AD) [12] and Hispano-Moresque glazed ceramics [13-16]. Although abundant information is available on the glaze recipes and the technological choices applied by Islamic potters related to diverse chronology and locations, few studies have addressed the compositional characterization of Almohad ceramic glazes and their connection to previous pottery productions.

In the case of Mallorca (Balearic Islands, Spain), the technological study of Islamic ceramics by means of archaeometric methods has only recently been implemented in relation to the petrographic study of pottery pastes $[6,17]$. Regarding the glazes of the vessels from this island, only the composition and technology of a very few samples $(n=6)$ related to the Taifa period (11th century AD) have been characterized [7,16]. A specific and systematic study of the technological choices and recipes applied by the Almohad potters in the production of glazed ceramics has never been conducted on the island. In this paper, we carry out the archaeometric study by means of SEM-EDS of the chemical composition and technology of an Islamic glazed ceramic assemblage for the first time on the island. The pottery studied was retrieved from the Almohad rural site of Puig de Sa Morisca (Figure 1). In this sense, it must be highlighted too that this is also the first time that the composition 
and technological features of a glazed ceramic assemblage recovered from a rural site of the Balearic Islands are studied.
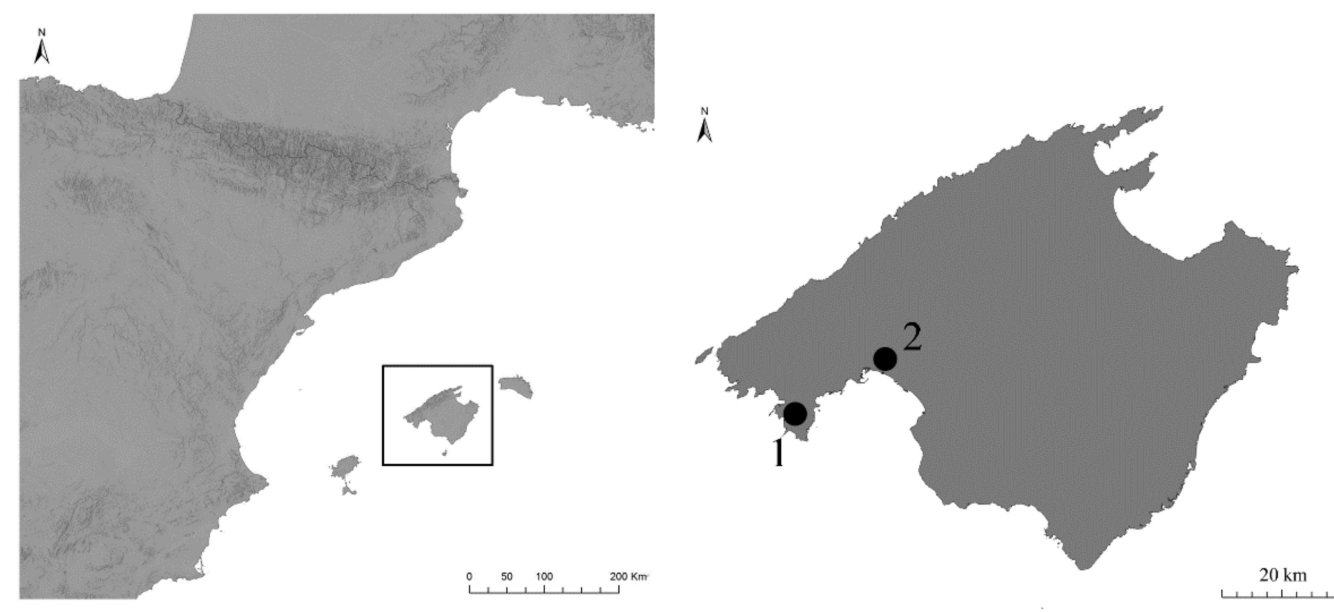

Figure 1. Geographic location of Mallorca and the archaeological sites mentioned in the text (1, Puig de Sa Morisca; 2, Madīna Mayūrqa/Palma).

The research that we present here focuses on approaching the Islamic glazed ceramics found on this archaeological site with three objectives. First, we aim to continue with the analyses conducted by other scholars $[7,18]$ and characterize the chemical composition and microstructure of late 12th and early 13th century glazes produced in the pottery workshops located in the main city of the island, Madīna Mayūrqa. Additionally, we will consider the features and particularities related to certain Islamic glazed ceramics that were imported to the island and subsequently distributed to some rural contexts. Finally, all this technological information will also be used to address the role played by the archaeological rural site of Puig de Sa Morisca during the Almohad period in order to provide a better understanding of the complexity of Islamic settlement before the Christian conquest of the island in 1229 [19].

\section{Archaeological Context}

The Islamic settlement at Puig de Sa Morisca is located in a rural area in southwest Mallorca (Balearic Islands, Spain). The Islamic site was built on top of an Iron Age site, reusing a prehistoric wall that protected the most accessible part of the $120 \mathrm{~m}$ hilltop where the site was placed. The rest of the $8500 \mathrm{~m}^{2}$ settlement has abundant Islamic ceramics on the surface and is inaccessible due to the steep rock face. The earliest Islamic occupation included a hearth reoccupying a prehistoric tower in the fortified hill dated to 970-1160 Cal AD (UTC-10027), i.e., an early Islamic occupation corresponding to the Taifa period (1009-1115). However, the largest Islamic remains recovered up to now were located on the hilltop and included three rooms of Almohad date (1202-1229) organized around an Iron Age tower with abundant Islamic ceramics on the surface [20].

The excavations inside these rooms carried out between 2002 and 2007 yielded a large collection of domestic and utilitarian ceramics similar to other rural contexts [21]: pitchers, jugs, marmites, ataifors (serving dishes), large jars, lids, tripods, alcadafes (basins), oil lamps, etc. [22]. The typologies and decorative techniques, together with the simplification of the stamped decoration, evidenced that the majority of the ceramic production dated back to the 12th and beginning of the 13th century AD, corresponding to the Almohad period $[20,22]$.

The petrographical and chemical analysis (WD-XRF) of the Islamic pottery recovered from the Almohad rural site of Puig de Sa Morisca [6,17] allowed us to identify the presence of a large set of ceramics, many of them glazed (Table 1), that were made with fine-textured calcareous clays with mudstones, calcimudstones, foraminifera and quartz (Petrofabric 1). The WD-XRF analysis conducted in 30 vessels from Petrofabric 1 allowed us to confirm the 
presence in the archaeological site of a monogenic and chemically very homogeneous group with a very low total variation $(v t=0.29)$, thus evidencing a common origin for all samples from this fabric. The petrographical features of the samples included in Petrofabric 1 and the study of the planktonic foraminifera present in the thin sections allowed us to relate the raw materials used in the production of these vessels to Pliocene clay deposits located on the Palma basin. Therefore, the archaeometric data available show that most of the vessels $(78 \%)$ recovered from the rural site of Puig de Sa Morisca had a local origin and were possibly made in pottery workshops located in the urban center of Madīna Mayūrqa (current city of Palma, Figure 1).

In addition, the petrographical analysis allowed us to verify the existence of a limited number of glazed vessels related to loners with a particular mineralogical composition on the rural site. These petrofabrics include intermediate-felsic plutonic igneous rocks (Petrofabric 4), low-grade metamorphic rocks (Petrofabric 5) or have a distinctive amount of quartz and K-feldspar (Petrofabric 8). Given the calcareous nature of Mallorca and the absence of igneous and metamorphic formations in the local geology, it is clear that these vessels were imported to the island and subsequently consumed and deposited on the rural site under study. 
Table 1. Typology, petrologic fabric and chemical composition of the glazes analyzed by means of SEM-EDS (wt $\%$, normalized to $100 \%$ ). n.d. $=$ non-detected * = concentrations determined by means of WD-XRF [6]

\begin{tabular}{|c|c|c|c|c|c|c|c|c|c|c|c|c|c|c|c|}
\hline Sample & Typology & Petro Fabric & \%CaO Body & Surface & Color & $\mathrm{Na}_{2} \mathrm{O}$ & $\mathrm{MgO}$ & $\mathrm{Al}_{2} \mathrm{O}_{3}$ & $\mathrm{SiO}_{2}$ & $\mathrm{~K}_{2} \mathrm{O}$ & $\mathrm{CaO}$ & $\mathrm{Fe}_{2} \mathrm{O}_{3}$ & $\mathrm{CuO}$ & $\mathrm{PbO}$ & $\mathrm{SnO}_{2}$ \\
\hline SM14 & Tajeen Lid & 1 & 16.7 * & Outer & Green & n.d. & 0.2 & 1.1 & 27.7 & 0.4 & 1.5 & 0.4 & 2 & 66.7 & n.d. \\
\hline SM21 & Juglet & 1 & $13.6^{*}$ & Outer & White & 1 & 0.3 & 3.2 & 34.9 & 1.4 & 3 & 0.9 & 1 & 49.8 & 4.5 \\
\hline SM23 & Ataifor & 1 & 8.8 & Inner & Green & n.d. & 0.4 & 3.4 & 33.2 & 0.7 & 2.5 & 1 & 2.3 & 56.5 & n.d. \\
\hline SM28 & Juglet & 1 & $7.8^{*}$ & Outer & Green & n.d. & 0.2 & 1.8 & 28.2 & 0.5 & 1.4 & 1.1 & 1.3 & 65.5 & n.d. \\
\hline \multirow{2}{*}{ SM29 } & \multirow{2}{*}{ Juglet } & \multirow{2}{*}{1} & \multirow{2}{*}{8.9} & Outer & Green & n.d. & 0.3 & 2.5 & 28.6 & 0.5 & 1.4 & 0.9 & 2.5 & 63.3 & n.d. \\
\hline & & & & Inner & Colorless & n.d. & 0.3 & 4 & 33.4 & 0.5 & 2.6 & 0.9 & n.d. & 58.3 & n.d. \\
\hline \multirow{2}{*}{ SM31 } & \multirow{2}{*}{ Orcita } & \multirow{2}{*}{1} & \multirow{2}{*}{8} & Outer & White & 1 & n.d. & 2.8 & 34.5 & 1.5 & 2 & 0.7 & 1.8 & 45.7 & 10 \\
\hline & & & & Inner & Colorless & n.d. & 0.3 & 3.5 & 26.5 & 0.4 & 1.3 & 0.8 & n.d. & 67.2 & n.d. \\
\hline SM32 & Ataifor & 1 & 9.4 & Inner & Green & n.d. & 0.6 & 5.5 & 38.4 & 1.7 & 3 & 1.7 & 2 & 47.1 & n.d. \\
\hline SM34 & Juglet & 1 & 13.3 & Outer & White & 1.8 & 0.4 & 3.6 & 32.6 & 1.8 & 2.6 & 1 & 1.1 & 52.2 & 2.9 \\
\hline SM36 & Ataifor & 1 & 12.2 & Inner & Colorless & n.d. & 0.6 & 5.1 & 27.2 & 1.1 & 4.8 & 3.7 & n.d. & 57.5 & n.d. \\
\hline SM37 & Pitcher & 1 & 10.7 * & Outer & Colorless & 0.3 & 0.7 & 5.6 & 30.9 & 1.3 & 5.3 & 2.8 & n.d. & 53.1 & n.d. \\
\hline SM39 & Ataifor & 1 & $8.6^{*}$ & Inner & Yellow & n.d. & 0.3 & 3.7 & 31.8 & 0.8 & 2.4 & 5.2 & n.d. & 55.8 & n.d. \\
\hline SM40 & Jar & 1 & 12.3 & Outer & Green & n.d. & 0.4 & 5.7 & 33.4 & 1.1 & 4.8 & 1.7 & 2 & 50.9 & n.d. \\
\hline \multirow{2}{*}{ SM41 } & \multirow{2}{*}{ Large Storage Pot } & \multirow{2}{*}{1} & \multirow{2}{*}{$6.2 *$} & Outer & Green & n.d. & 0.2 & 2.3 & 29.2 & 0.4 & 1.1 & 0.9 & 0.6 & 65.3 & n.d. \\
\hline & & & & Inner & Colorless & n.d. & 0.2 & 1.9 & 29 & 0.3 & 1.3 & 0.8 & n.d. & 66.5 & n.d. \\
\hline SM42 & Ataifor & 1 & 17.5 & Inner & White & 1.5 & 0.3 & 3.7 & 34.4 & 1.5 & 2.6 & 1.1 & 1.7 & 49 & 4.2 \\
\hline SM43 & Storage Pot & 1 & 17.2 & Outer & Green & n.d. & 0.3 & 3.1 & 31.8 & 1.3 & 2.8 & 0.8 & 1 & 58.9 & n.d. \\
\hline SM44 & Ataifor & 1 & 11.9 & Inner & White & 1.5 & 0.2 & 2 & 34 & 0.9 & 1.8 & 0.9 & 0.6 & 53.7 & 4.4 \\
\hline SM47 & Juglet & 5 & 5.6 & Outer & Colorless & 0.3 & 0.6 & 5 & 35.9 & 1.1 & 1.1 & 2.7 & n.d. & 53.3 & n.d. \\
\hline SM48 & Ataifor & 1 & 9 & Inner & White & 1.2 & 0.3 & 2.9 & 34.9 & 1.2 & 1.7 & 0.8 & 1.3 & 50.4 & 5.3 \\
\hline SM49 & $\begin{array}{c}\text { Candle-Style Oil } \\
\text { Lamp }\end{array}$ & 1 & 10.3 & Outer & Green & n.d. & 0.3 & 3.1 & 33.9 & 0.7 & 2.3 & 0.9 & 2.4 & 56.4 & n.d. \\
\hline
\end{tabular}


Table 1. Cont.

\begin{tabular}{|c|c|c|c|c|c|c|c|c|c|c|c|c|c|c|c|}
\hline Sample & Typology & Petro Fabric & $\%$ CaO Body & Surface & Color & $\mathrm{Na}_{2} \mathrm{O}$ & $\mathrm{MgO}$ & $\mathrm{Al}_{2} \mathrm{O}_{3}$ & $\mathrm{SiO}_{2}$ & $\mathrm{~K}_{2} \mathrm{O}$ & $\mathrm{CaO}$ & $\mathrm{Fe}_{2} \mathrm{O}_{3}$ & $\mathrm{CuO}$ & $\mathrm{PbO}$ & $\mathrm{SnO}_{2}$ \\
\hline SM51 & Oil Lamp & 1 & 16.4 & Outer & Colorless & n.d. & 0.5 & 3.6 & 32.2 & 0.7 & 3.7 & 2.1 & n.d. & 57.2 & n.d. \\
\hline SM56 & Ataifor & 4 & 15.5 & Inner & Green & 1 & 0.3 & 1.3 & 29.3 & 1.1 & 2.3 & 0.8 & 1.7 & 62.2 & n.d. \\
\hline \multirow{2}{*}{ SM57 } & \multirow{2}{*}{ Ataifor } & \multirow{2}{*}{8} & \multirow{2}{*}{17.5} & Inner & Green & 0.6 & 0.4 & 4.6 & 33.4 & 2 & 4.2 & 0.9 & 3 & 50.9 & n.d. \\
\hline & & & & Outer & Colorless & 0.2 & 0.7 & 7.8 & 30.9 & 1.8 & 7.4 & 1.9 & n.d. & 49.3 & n.d. \\
\hline \multirow{2}{*}{ SM58 } & \multirow{2}{*}{ Ataifor } & \multirow{2}{*}{1} & \multirow{2}{*}{8.1} & Inner & Green & 0.3 & 0.6 & 2.2 & 28.7 & 0.9 & 4.2 & 0.9 & 2 & 60.2 & n.d. \\
\hline & & & & Outer & Colorless & n.d. & 0.5 & 3.4 & 33.9 & 0.9 & 3.7 & 1.2 & n.d. & 56.4 & n.d. \\
\hline \multirow{2}{*}{ SM59 } & \multirow{2}{*}{ Ataifor } & \multirow{2}{*}{5} & \multirow{2}{*}{15.5} & Inner & Green & n.d. & 0.2 & 3.5 & 33.6 & 1.4 & 2.7 & 1 & 3 & 54.6 & n.d. \\
\hline & & & & Outer & Yellow & n.d. & 0.3 & 2.9 & 31.2 & 1.4 & 3.2 & 4.4 & n.d. & 56.6 & n.d. \\
\hline
\end{tabular}




\section{Materials and Methods}

We analyze in this paper the chemical and mineralogical composition and the microstructure of 25 glazed ceramic samples that comprehend the wide typological diversity of glazed pottery identified on the archaeological site of Puig de Sa Morisca: pitchers, jugs, serving dishes, jars, lids, oil lamps, etc. (Table 1; Figure 2) [22]. The vast majority of the samples under study $(n=20)$ were classified in Petrofabric 1 and are, therefore, related to local productions. In addition, the other five glazed ceramics, classified by their particular petrographic composition as loners and associated with imported wares, were also considered in the analysis (Table 1). The analysis of the glazes was conducted by cutting small fragments of the glazed pottery samples perpendicular to the glaze-body interface (including the body and the glazes located on the inner and outer surface of the vessels) with a diamond saw.

\section{a}

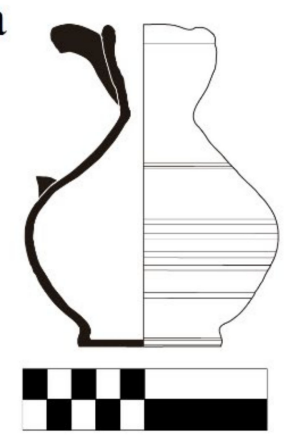

b

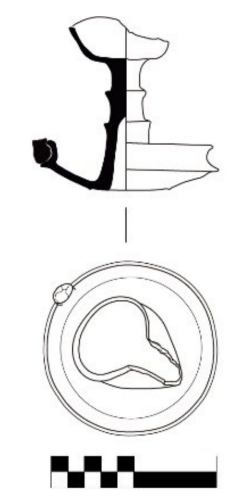

c

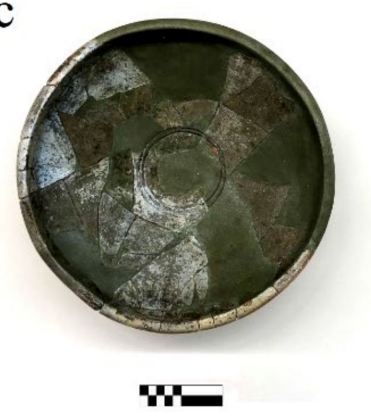

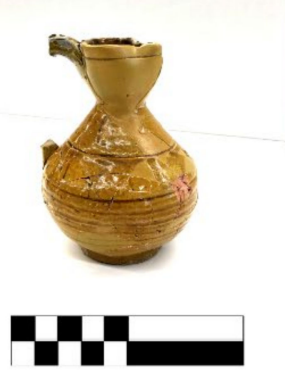
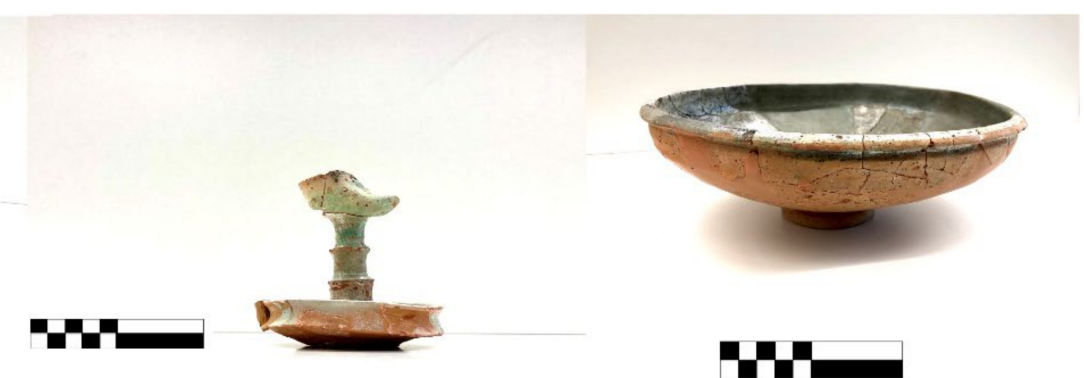

M

Figure 2. Photos and drawings of some of the glazed vessel typologies studied from Puig de Sa Morisca: (a) juglet (redoma), (b) candle-style oil lamp and (c) serving dish (ataifor). All the scale bars $=10 \mathrm{~cm}$.

Polished cross-sections were prepared for examination in a JEOL JSM 6610 LV scanning electron microscope (SEM) (Jeol Ltd., Tokyo, Japan) equipped with an Oxford Instruments XMAXN 50 energy-dispersive spectrometer (EDS) (Oxford Instruments, Abingdon, United Kingdom). Quantitative analyses of the glazes were carried out using the EDS at $20 \mathrm{kV}$ and scanning large areas of the glaze at $2000 \times$, avoiding crystals related to the bodyglaze interface, inclusions and any weathered or contaminated surface layers. However, sometimes evenly distributed inclusions, such as tin oxide particles, were necessarily included in the analysis. The reported values of the glazes are the averages of 10 analyses spread over the glaze layer in each sample.

Former WD-XRF data from Albero et al. [6] was used to record the CaO content of the ceramic body. However, not all the glazed samples analyzed in this study were formerly characterized by means of WD-XRF. In these cases, SEM-EDS scans of the clay matrix were also conducted in order to approach the calcareous/non-calcareous nature of the clay matrix. The $\mathrm{CaO}$ content of the matrix of each sample relates to the average of between 
two and three microanalyses at $2000 \times$ magnifications, avoiding inclusions appearing on the clay body.

The analysis of the microstructure of the clay body was also carried out at $2000 \times$ magnifications using secondary electrons. The stability of the beam current during all these processes was monitored by calibrating against a cobalt standard. The accuracy and precision of the systems employed were checked against Corning B, C and D reference glasses. The limit of detection (LOD) of the instrument was only made possible to detect those elements with a weight greater than $0.2 \%$ of the total sample. All quantitative results of the glazes and clay matrix are reported as normalized weight per cent oxides with oxygen determined by stoichiometry.

\section{Results}

\subsection{Local Pottery Production (Petrofabric 1)}

The glazes identified in the archaeological vessels related to Petrofabric 1 are often slightly corroded, giving many samples a worn and dull appearance. The SEM-EDS analysis of the glazes provides evidence of the application of a vitreous layer between 60 and $200 \mu \mathrm{m}$ thick (although in some cases it can be up to $750 \mu \mathrm{m}$ ) generally rich in $\mathrm{PbO}(47-67 \%)$, thus suggesting the use of lead-silica glazes. The alkali content is low $\left(\mathrm{K}_{2} \mathrm{O}<2 \%\right.$ and $\left.\mathrm{Na}_{2} \mathrm{O}<2 \%\right)$ and probably related to impurities present in the raw materials and chemical diffusion from the body paste during firing [7]. Therefore, lead is the main flux in these vitreous layers, many of them translucent (e.g., SM-36, SM-37, SM-51), since they did not incorporate colorants into their composition (Table 1; Figure 3a). However, most sherds under study show a green or greenish-white color on their surface.

a

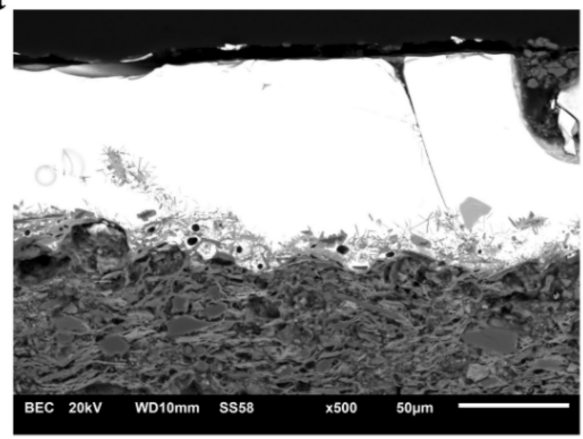

C

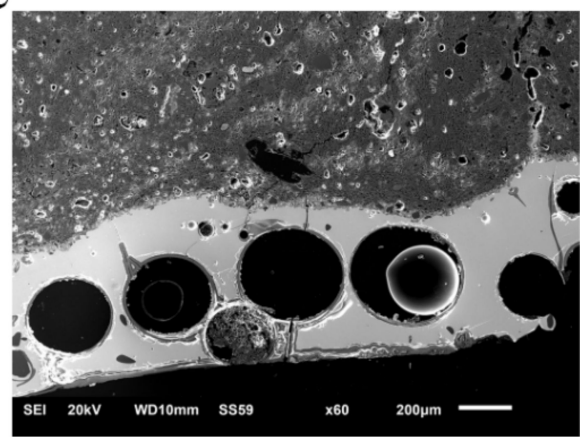

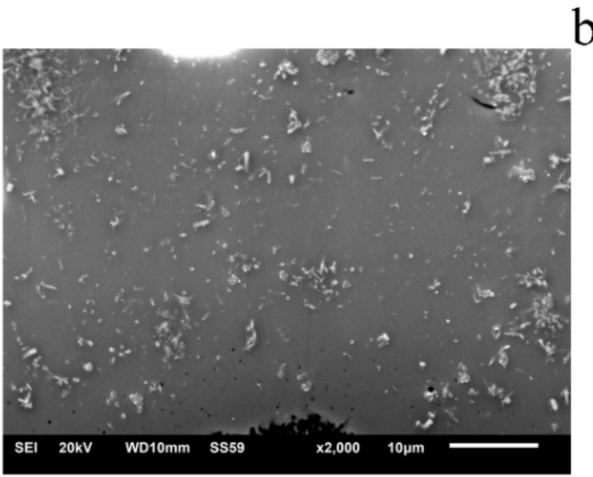

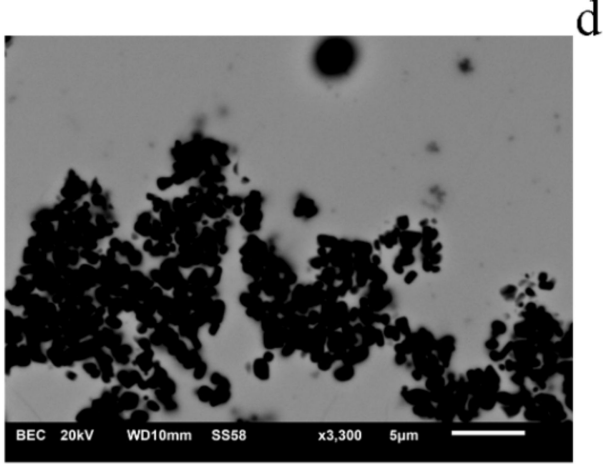

Figure 3. (a) Back-scattered electron image showing a well-preserved thin glaze layer (SM-40), (b) Secondary electron image of cassiterite crystals in glaze of the sample SM-44, (c) Secondary electron image showing bubbles resulting from probably intentional gas release during the application of the glaze (SM-14), (d) Back-scattered electron image (BSEI) showing aggregates of equant pyroxene crystals in SM-14.

As could also be observed elsewhere and in other pottery samples from Al-Andalus [7,23,24], we identify the use of tin glazes in six ceramics. In our case, the glazes have a significant 
$\mathrm{PbO}$ content $(45.7-67.2 \%$; average $=56.81 \%, \sigma=6.31)$ and a lower amount of tin oxide (3-10\%). Therefore, these are glazes made of lead, silica, a low amount of sodium-alkali fluxes and $\mathrm{SnO}_{2}$ as opacifier. In these cases, the presence of $\mathrm{SnO}_{2}$ in the glazes (Figure 3b) probably related to the formation of cassiterite crystals [16] -allowed the potters to obtain a white opaque layer. These crystals are usually between $700-800 \mathrm{~nm}$ in size, although some of them can be up to $3.5 \mu \mathrm{m}$. Generally, the crystals are heterogeneously distributed through the glass, greatly affecting the tin oxide concentrations recorded in different parts of the glaze. This variability can be clearly confirmed in the high standard deviation and coefficient of variation recorded for the $\mathrm{SnO}_{2}$ values $(\sigma=1.45-7.15$; c.v. $=0.33-0.71)$. The low amount of tin used (usually $<5 \%$ ) would not have been enough to successfully opacify the surface of the vessels. Therefore, semi-opaque glazes were obtained in which the color of the paste would have been slightly visible, providing a pinkish-greenish tone to the surface of the ceramics.

As observed in other tin-glazed Islamic ceramics from Mallorca [7], a small amount of copper (1-2\%) was also added to the tin glazes analyzed (Table 1$)$. This element would have generated a pale green-turquoise-colored glaze. As it is usual in this kind of tin glazes, the surfaces of the samples under study are highly corroded. As we previously noted, the loss of brightness and vitreous appearance is obvious even at the macroscopic level in these cases. The alkali $\left(\mathrm{Na}_{2} \mathrm{O}\right.$ and $\left.\mathrm{K}_{2} \mathrm{O}\right)$ and alumina content is less than $4 \%$. The iron concentrations are up to $1.1 \%$, which indicates that the ceramic body did not affect the chemical composition of the glass.

It is interesting to note that there is one case (SM-14) without tin in which we observe abundant microscopic bubbles (Figure 3c). These bubbles were formed by the occlusion of gases released in the molten glass from the decomposition of particles from the ceramic body (e.g., organic materials, carbonates, sulphates, hydrates) during the firing process. In normal conditions, these bubbles dissipate when the glazes are melted at a proper temperature. Once the cooling process starts, these bubbles cannot be eliminated. Therefore, the presence of these micro-bubbles in this glaze can be related to a lower firing temperature in this sample [25]. Other scholars recorded the presence of bubbles in ceramic glazes from Al-Andalus $[7,9,26]$. Their presence in the glazes seems to be associated with firing failures. Considering that this technological process has been identified (within the studied assemblage) only in this single vessel, we can point to a production failure in this case. However, we cannot dismiss that the formation of a significant amount of bubbles could also have been intentional in SM-14. It is well documented that Islamic potters also used gas bubbles locked in the glaze during the firing to reduce transparency and opacify the surface of the vessels [25,27].

The regular presence of crystalline silicates (sometimes forming aggregates) in the glazes studied, such as wollastonite (calcium silicate) or diopside (calcium magnesium silicate) (Figures $3 \mathrm{~d}$ and $4 \mathrm{a}$ ), which originated during the firing process, would also have contributed to opacifying the surfaces of the vessels [5,28].

It should also be noted that, as observed in other Islamic ceramics $[7,29]$, there was a clear preference in all the samples analyzed (i.e., in both lead glazes and tin glazes) for using calcareous pastes to apply the glazes. The clay body of the local samples analyzed shows $\mathrm{CaO}$ concentration between 6.2-17.5\%. According to Tite et al. [30], the coefficient of thermal expansion of calcite is very similar to that recorded in lead glazes. This aspect would have prevented the formation and propagation of cracks and fractures during the cooling and heating processes involved in pottery production. Moreover, the presence of iron (an element that is very common in calcareous pastes) would have promoted a higher degree of opacity in the tin glazes applied [31].

The thickness of the clay-glaze interface (Figures $3 a$ and $4 b$ ) —usually of 5-10 $\mu \mathrm{m}$ $(<20 \mu \mathrm{m})$ - and the limited development of $\mathrm{Pb} \mathrm{K}$ feldspars suggest that glazes were applied in two separate firings in all samples analyzed $[5,7,18]$. Following the usual process of Al-Andalus pottery productions [32], a first firing process took place in order to fire the clay, while a second process was subsequently developed for glazing. In this sense, the use 
of a double firing would have promoted more homogeneous and flawless surfaces. The diopside and wollastonite crystals identified in many samples would have been formed during the firing of the glaze [18].
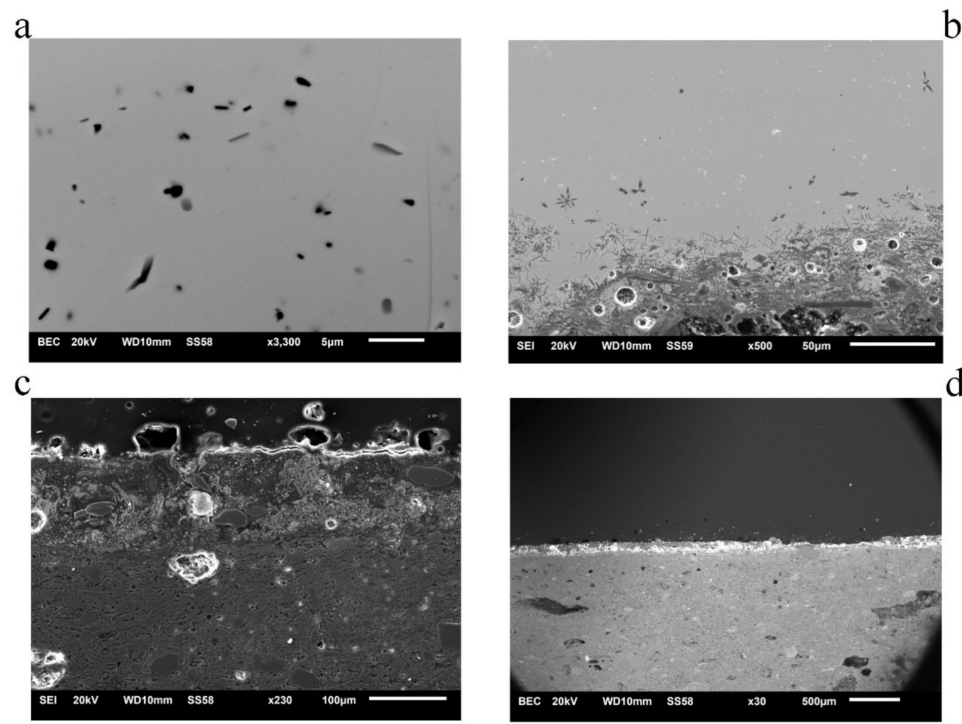

Figure 4. (a) Back-scattered electron image (BSEI) showing acicular crystals of wollastonite (SM-28), (b) Secondary electron image showing the growth of sanidine crystals in the interface located between the glaze and the clay body (SM-37), (c) Secondary electron image showing the weathered alkaline glaze and the tin oxide layer identified in SM-38, (d) Back-scattered electron image taken at low magnifications showing the distribution of the tin oxide layer over the surface of the sample (SM-38).

In addition, we identified five samples (a juglet/redoma, a small closed container/orcita, a jar/jarro, a serving dish/ataifor and a storage pot/orza) that are glazed on both the inner and the outer surfaces (Table 1). The glazes on each side show a different composition. One of them (usually the outer and most visible surface) has between $0.6 \%$ and $2.5 \% \mathrm{CuO}$, which is the amount necessary to provide a neutral green color to the glaze. In all these cases, the vessels were produced using lead-silica glazes, not tin glazes. Therefore, these ceramics have a translucent glaze on one of their surfaces, while the other one shows the addition of $\mathrm{CuO}$ with the aim to promote a green coloration [32]. These results demonstrate the use of different recipes to produce the inner and outer surfaces of the vessels. Furthermore, we document the addition of iron on the inner surface of the ataifor SM-39, probably with the aim to provide a yellowish-brown coloration [32]. In this case, the amount of iron $(\mathrm{FeO}=5.2 \%)$ doubles the concentrations observed in the other samples.

\subsection{Imported Wares}

The glazed imported wares consist mainly of serving dishes or ataifor $(n=4)$ and a colorless juglet (redoma). Although these vessels are associated with different petrofabrics and origins [6], we document that almost all the glazes were applied following the same technological choices observed in the ceramic assemblage associated with local productions. On the one hand, we confirm the use of lead as the main flux in these vitreous layers $(\mathrm{PbO}=49-62 \%)$ and a low alkali content $\left(\mathrm{K}_{2} \mathrm{O}=<2 \% ; \mathrm{Na}_{2} \mathrm{O}=<0.6 \%\right)$. On the other hand, the glazes were also applied on calcareous pastes $(\mathrm{CaO}=5-17.5 \%)$. Finally, we also verify the addition of copper $(\mathrm{CuO}=1.7-3 \%)$ on the glazes located on the inner surface of the serving dishes (ataifor) in order to provide their characteristic greenish color. In spite of these similarities, we observe that some of these imported vessels are singular within the ceramic assemblage under study. This is the case with the ataifor SM-59, which has the typical inner green glaze $(\mathrm{CuO}=3 \%)$ but also the addition of iron $(\mathrm{FeO}=4.4 \%)$ on the outer glazed layer, thus providing a yellowish coloration to the external surface of the vessel (Table 1; Figure 5). Therefore, we can conclude that this imported ceramic was produced 
using more complex technological procedures and glazed recipes than the other vessels located on the site, as it incorporates two different colorants on its surfaces.
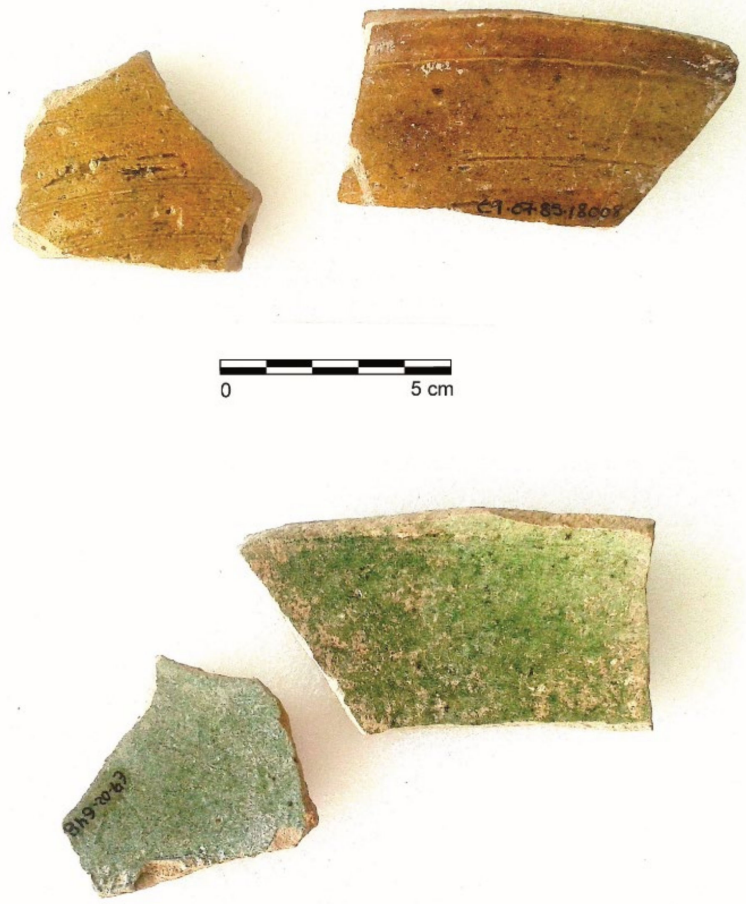

Figure 5. Photos of the inner and outer glaze layers of the imported sample SM-59.

We could not detect the use of tin to opacify the surfaces of the imported ceramics analyzed. However, we observed the use of a peculiar technological choice to opacify the surface of the vessel in one case. This is the case of the ataifor SM-38 (Figures 4 and 6), decorated with black strokes painted on a white background [33]. This pottery, which was imported to the island, is certainly particular within the ceramic assemblage studied for its decoration, typology, chronology (ca. late 10th century to 12th century AD) and technology. This sample is the only one that shows the application of an alkaline glaze. This glaze is completely degraded (Figure 3c), showing, as a result of corrosion, the presence of phosphates and carbonates. The high degree of corrosion prevents an accurate quantitative chemical analysis of this sample (this is the reason why SM-38 does not appear in Table 1). However, some interesting technological aspects can be pointed out from its study by means of SEM-EDS.

We are able to confirm that the presence of $\mathrm{PbO}$ in the glaze is much lower in this sample, evidencing that it is not related to a lead-silica glaze. In contrast, the amount of alkalis is significantly higher. Although we must consider that there could have been a loss of alkalis (such as $\mathrm{Na}_{2} \mathrm{O}$ ) as a result of the degradation of the glaze, we observe that (in spite of being degraded) the $\mathrm{K}_{2} \mathrm{O}$ content is four times higher in this sample. The glaze located on the outer surface of the vessel shows a low amount of $\mathrm{SnO}_{2}$, which would have contributed to opacify the layer. The glaze applied on the inner surface of the pot has the same characteristics as the external one, but in this case, it is thicker $(120 \mu \mathrm{m})$ and shows a layer very rich in $\mathrm{SnO}_{2}$ between the glaze and the ceramic body (Figure $4 \mathrm{~d}$ ).

The location of this $\mathrm{SnO}_{2}$ layer, together with the absence of the crystals usually observed in the tin glazes, suggests that the surface of this ceramic was opacified using a layer of powdered tin that was firstly applied to the ceramic body as a slip and was subsequently coated with a transparent alkaline glaze. The distinctive features of this glaze point to the use of a lead-tin alkaline frit [24]. Frequent rounded quartz grains of up to $50 \mu \mathrm{m}$ are documented in this glaze. Such relic silicate inclusions in the glazes suggest the direct use of quartz-rich sand. As a consequence of the use of a high amount of tin oxide, 
the inner surface of this vessel has a high degree of opacity, something advisable if black paint is going to be applied on such surface. While this technological choice to opacify the pottery surface is unique within the analyzed record, it has been documented in the Near/Middle East since the 8th century. It has been related to the deliberate application of a tin oxide slip [23] but also as a result of settling out of tin oxide due to deflocculation that occurs in a high-alkali glaze [23].
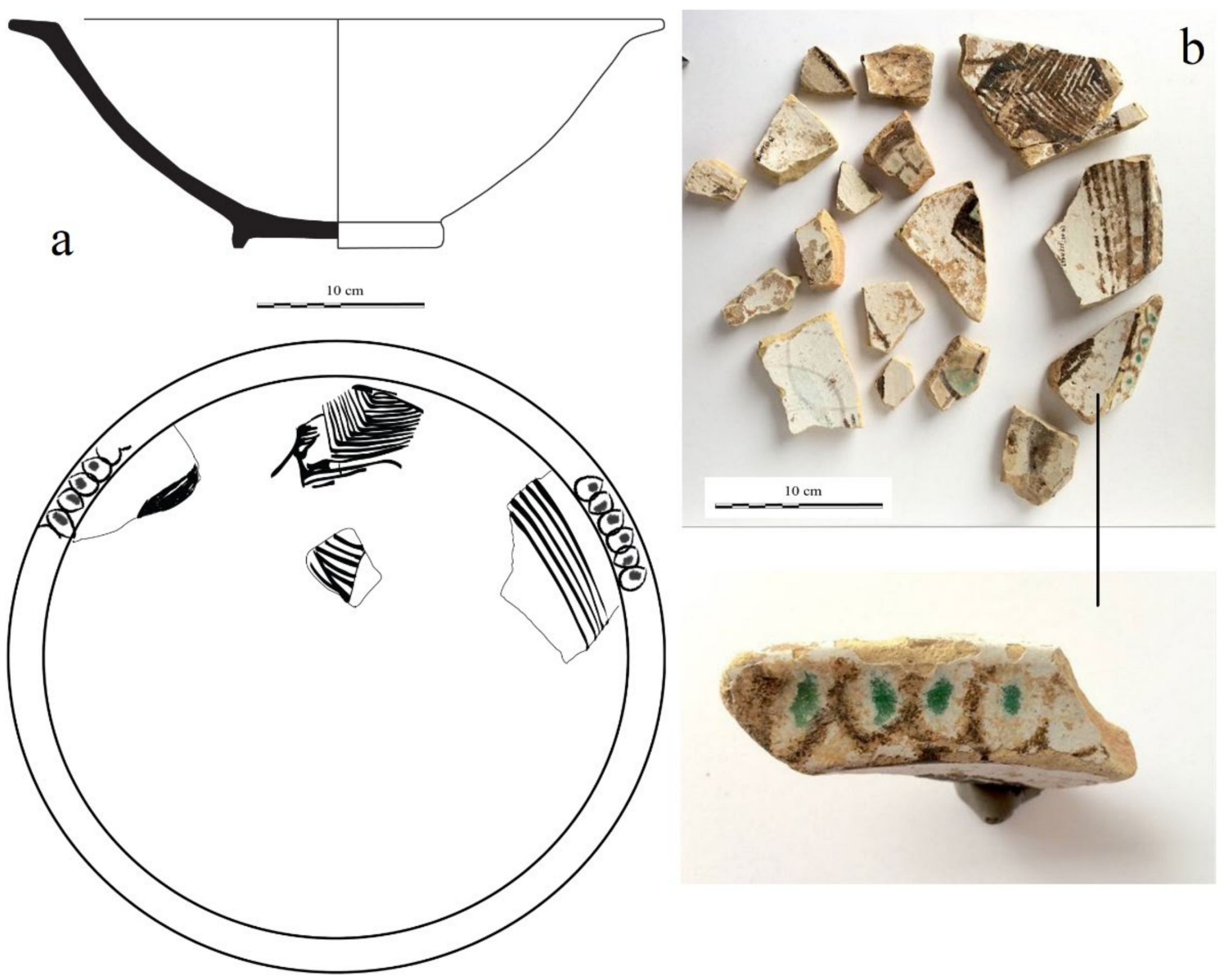

Figure 6. (a) Drawing of the imported ataifor SM-38 and (b) photos of the white opaque glazed layer and the decorative motifs applied.

\section{Discussion}

The SEM-EDS analyses of the glazes associated with the local productions allegedly related to Madina Mayūrqa pottery workshops demonstrate the use of the same recipe for vessels associated with a wide range of typologies. In this sense, we see how the amount of $\mathrm{PbO}$ used as flux is highly standardized $(\mathrm{CV}=0.11)$ in the ceramics classified in the Petrofabric 1 . This statement fits well with the high standardization and technical sophistication recorded in Almohad pottery productions [34], which are traditionally related to specialized productions developed in urban workshops [35]. In this sense, Almohad ceramics have been typically regarded as an improvement on previous surface treatments, indicating a sensible change in production strategies [36]. Nevertheless, the glazes studied in this research provide evidence that there is a clear compositional continuity with the glazed pottery productions developed in Palma in the 11th century AD [7], both with regard to the use of lead as flux, the addition of tin as opacifier and copper as colorant. The concentrations of these chemical elements $\left(\mathrm{PbO}, \mathrm{Sn}_{2} \mathrm{O}\right.$ and $\left.\mathrm{CuO}\right)$, and of the alkaline elements recorded in the studied Almohad pottery glazes, fit well with the ranges observed in ceramics from Madīna Mayūrqa dating from the Taifa period (Table 2). 
Table 2. Comparison of the chemical average concentrations (\%wt) observed by means of SEM-EDS between Taifa and Almohad pottery glazes from Mallorca. ${ }^{*}=$ Values recorded from Molera et al. [7].

\begin{tabular}{ccc}
\hline & $\begin{array}{c}\text { Taifa Glazes * } \\
\text { (11th Century) }\end{array}$ & $\begin{array}{c}\text { Almohad Glazes } \\
\text { (12-13th Centuries) }\end{array}$ \\
\hline $\mathrm{SiO}_{2}$ & $31 \%$ & $31.9 \%$ \\
$\mathrm{PbO}$ & $54 \%$ & $56.8 \%$ \\
$\mathrm{Al}_{2} \mathrm{O}_{3}$ & $3.2 \%$ & $3.3 \%$ \\
$\mathrm{SnO}_{2}$ & $7-9 \%$ & $5.2 \%$ \\
$\mathrm{~K}_{2} \mathrm{O}$ & $1.2 \%$ & $0.9 \%$ \\
$\mathrm{Na}_{2} \mathrm{O}$ & $1 \%$ & $1 \%$ \\
$\mathrm{CuO}$ & $1.6 \%$ & $1.6 \%$ \\
\hline
\end{tabular}

Regarding the use of tin as opacifier, we see that this technological choice is usually related to tableware, mainly with ataifors (SM-42, SM-44, SM-48) and two small bottles (redoma). Likewise, the generation of bubbles, perhaps to provide an opaque surface, is also documented in a tableware vessel related to a lid or tajeen (SM-14). In addition, we also see some interesting correlations between the typology and the technology of certain glazed ceramics intended for the same function. This is the case with the oil lamps; we see how the oil lamp analyzed has a simple colorless glazed layer, while the candle-style oil lamp studied is associated with a more elaborated technique, since in this sample, $\mathrm{CuO}$ was added to the glaze in order to provide a greenish color to the outer surface of the vessel (Figure 2).

In agreement with the data available from other studies and diverse locations [7], the glazes of the imported ceramics recovered from the site show (except for sample SM-38) the same technical choices identified in the production of local pottery. This provides evidence of the high degree of standardization of the Al-Andalus ceramic productions as a whole, where the techniques applied were well established and shared among the different regions.

Despite the fact that most of the imported wares were made by means of the same technological procedures applied in the production of local glazed vessels, we also confirm that there are certain glazed samples that are unique within the analyzed ceramic assemblage. The decoration of these singular tableware potteries was clearly designed for exhibition and visualization. Such luxurious Islamic ceramics are usually found in urban contexts, being rather unusual on rural sites [37]. In this sense, two of the three bichrome serving dishes recovered from the rural archaeological site studied are related to ceramics that were imported to the island. Furthermore, one of them (SM-59) depicts higher technical complexity, since it is the only vessel analyzed that shows the application of different kinds of colorants on each of its surfaces.

The serving dish SM-38 is also unique within the ceramic assemblage studied, both due to its older chronology and the use of a layer very rich in tin to opacify the surface of the vessel. This ceramic represents a relic that clearly stands out among the Almohad pottery recovered from the rural site of Puig de Sa Morisca. The presence of this vessel-which is very unusual in rural contexts-on this site must be related to the owner's interest in keeping and protecting this object over time, perhaps because of its distinctive foreign origin, its greater economic value or its social significance. In this sense, this vessel could have promoted a sense of belonging related to the owner's life history. This type of ataifor can be related to the so-called bacini, which were imported to the Pisa area in Italy. The archaeometric analyses carried out on these types of luxurious, technically elaborated and exquisitely decorated masterpieces, suggest that they were imported from southern Al-Andalus [38].

In Islamic times, commerce was mainly articulated by coastal navigation, resorting to anchorage and coastal references [39]. In this sense, the geostrategic position of Puig de Sa Morisca-located in the main port to the west of the island (i.e., Santa Ponsa) and one of the most important references for coastal navigation in the region (Figure 7a)—could 
have favored the distribution of some imported items towards this settlement. In this sense, given the strategic location of the Puig de Sa Morisca site in a coastal area with an intense commercial tradition $[6,20]$, the arrival of these imported singular vessels on the site due to trade or plunder (activity well documented during the rule of Al-Muwaffaq and his son Ali Iqbāl al-Dawla) cannot be dismissed. Thus, we can suggest that this vessel could have been part of a larger set of ceramics, with its final destination being the ports of Tuscany, that ended up in the port of Madīna Mayūrqa or perhaps even in the port of Santa Ponsa [33].
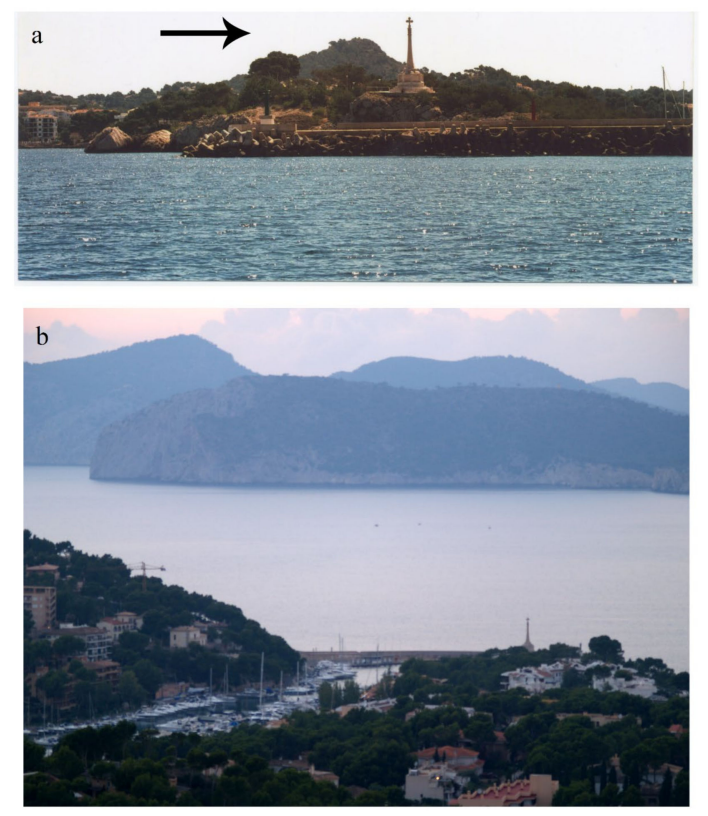

Figure 7. Location of the archaeological site of Puig de Sa Morisca. (a) Views of the site from the sea (Source: ArqueoUIB research group) and (b) visual control of the coastal area and the port from the hilltop.

The presence of unique and more elaborated imported tableware such as this in nonurban contexts such as Puig de Sa Morisca allows us to perhaps rethink the role of this site, which could have gone beyond a mere fortified rural location (hisn) linked to the peasant communities that inhabited the area. In this sense, it can be suggested that, given its geostrategic position, Puig de Sa Morisca could have developed some kind of function as a coastal reference point for trade during the Islamic period and even for the visual control of one of the main landing ports of the island (Figure 7b). In this sense, it is worth highlighting that several Christian contingents landed in this area of the island during the 13th and 14th centuries AD [19]. It is necessary to conduct further archaeometric analysis and multiproxy approaches on rural ceramic assemblages and urban contexts from Mallorca in order to shed light and confirm the singular nature of the rural site of Puig de Sa Morisca and its role in the Islamic settlement pattern and trade networks.

\section{Conclusions}

The diverse recipes and techniques applied by Almohad potters from Mallorca to glaze the ceramics were identified by means of SEM-EDS. The technological choices recorded are in agreement with other pottery productions from Al-Andalus. The exclusive use of leadsilica glazes is verified, which in some cases were opacified by the addition of tin or, less commonly, by means of the generation of bubbles. In addition, the formation of crystalline silicates also contributed to opacifying the surface of the vessels. The addition of $\mathrm{CuO}$ and $\mathrm{FeO}$ to the glaze was also confirmed for the Almohad local productions of Mallorca. These materials were added with the aim to provide a neutral green and yellowish-brown color to the pottery surfaces, respectively. The thickness of the interface between clay and glaze, 
together with the limited development of sanidine crystals, demonstrates that these glazes were applied in two firings and on calcareous ceramic pastes.

Finally, we confirm that some of the glazed ceramics that were imported to the island show certain particularities. Two of the imported ataifors recorded on the site are bichrome (one of them has a very high iron content), while another one features an alkaline glaze, very unique in the assemblage. The presence of these particular ceramics allows us to suggest that perhaps the site of Puig de Sa Morisca played a more complex role and carried out functions that went beyond the defense of a peasant group.

Author Contributions: Conceptualization: D.J.A.S., J.C.C.L. and A.R.B.; methodology: D.J.A.S. and J.C.C.L.; formal analysis: D.J.A.S. and A.R.B.; investigation: D.J.A.S.; resources: J.C.C.L.; writingoriginal draft preparation: D.J.A.S.; writing—review and editing: D.J.A.S., J.C.C.L. and A.R.B.; project administration: D.J.A.S.; funding acquisition: D.J.A.S. and J.C.C.L. All authors have read and agreed to the published version of the manuscript.

Funding: This research was funded by a José Castillejo grant CAS15/00052 (research mobility program for lecturers in foreign educational and research centers) from the Ministerio de Educación, Cultura y Deporte (Spain).

Acknowledgments: Preparation of samples and SEM-EDS analysis was carried out in the Laboratory of Archaeological Materials Science (University College London Qatar). We would like to thank Thilo Rehren and Myrto Georgakopoulou for giving us access to the facilities.

Conflicts of Interest: The authors declare no conflict of interest.

\section{References}

1. Bridgman, R. Re-examining Almohad economies in south-western Al-Andalus through petrological analysis of archaeological ceramics. In Revisiting al-Andalus: Perspectives on the Material Culture of Islamic Iberia and beyond; Anderson, G.D., Rosser-Owen, M., Eds.; Brill: Leiden, The Netherlands, 2007; pp. 143-166.

2. Bridgman, R. Contextualising pottery production and distribution in South-Western al-Andalus during the Almohad period: Implications for understanding economy. In Atti del IX Congresso Internazionale sulla Ceramica Medievale nel Mediterraneo; All'Insegna del Giglio: Firenze, Italy, 2012; pp. 95-100.

3. García Porras, A.; Capelli, C.; Cabella, R.; Romero, J.; Cardell, C. Ceramic production in Granada and in the southeast of the Iberian Peninsula during the late Middle Ages: Clays, tools and pots-Some preliminary notes. Mediev. Ceram. 2011, 32, $29-43$.

4. Pérez-Arantegui, J.; Hernández Pardos, A. Caracterización arqueométrica de la cerámica del castillo de Albarracín (Teruel, España) en la transición entre los siglos XII y XIII. DigitAR 2017, 4, 41-50. [CrossRef]

5. Molera, J.; Pradell, T.; Merino, L.; García-Vallés, M.; García-Orellana, J.; Salvado, J.; Vendrell-Saz, M. La tecnología de la cerámica islámica y mudéjar. Cesaraugusta 1997, 73, 15-41.

6. Albero Santacreu, D.; Mateu Vicens, G.; Ramos Benito, A.; Carvajal López, J.C.; Georgakopoulou, M. Pottery in the backyard: Almohad ceramic distribution networks in rural areas (SW Mallorca, Spain). Archaeol. Anthropol. Sci. 2019, 11, 4769-4788. [CrossRef]

7. Molera, J.; Vendrell-Saz, M.; Pérez-Arategui, J. Chemical and textural characterization of tin glazes in Islamic ceramics from Eastern Spain. J. Archaeol. Sci. 2001, 28, 331-340. [CrossRef]

8. González García, F.; González Rodríguez, M.; González Vílchez, C.; Vallejo Triano, A. Estudio arqueométrico de algunas cerámicas medievales de Madinat Al-Zahra (Córdoba). Boletín de la Sociedad Española de Cerámica y Vidrio 1992, 31, 491-498.

9. Molera, J.; Carvajal López, J.C.; Molina, G.; Pradell, T. Glazes, colourants and decorations in early Islamic glazed ceramics from the Vega of Granada (9th to 12th centuries CE). J. Archaeol. Sci. Rep. 2018, 21, 1141-1151. [CrossRef]

10. Salinas, E.; Pradell, T.; Tite, M.S. Tracing the tin-opacified yellow glazed ceramics in the western Islamic world: The findings at Madīnat al-Zahrā'. Archaeol. Anthropol. Sci. 2019, 11, 777-787. [CrossRef]

11. Pradell, T.; Molina, G.; Molera, J.; Marinetto, P. Primeros resultados del estudio analítico de la cerámica vidriada decorada Nazarí: La cerámica palatina (ss. XIV-XV). In Actas del I Congreso Internacional Red Europea de Museos de Arte Islámico; Universitat Politècnica de Catalunya: Barcelona, Spain, 2012; pp. 397-418.

12. Pérez-Arantegui, J.; Marzo, P. Characterization of Islamic ceramic production techniques in Northeast Iberian Peninsula: The case of medieval albarracin (Spain). Appl. Sci. 2021, 11, 7212. [CrossRef]

13. Molera, J.; Pradell, T.; Martínez, S.; Vendrell, M. The growth of sanidine crystals in the lead glazes of Hispano-Moresque pottery. Appl. Clay Sci. 1993, 7, 483-491. [CrossRef]

14. Molera, J.; Vendrell-Saz, M.; García-Vallés, M.; Pradell, T. Technology and colour development of hispano-moresque lead-glazed pottery. Archaeometry 1997, 39, 23-39. [CrossRef]

15. Pérez-Arantegui, J.; Larrea, A.; Molera, J.; Pradell, T.; Vendrell-Saz, M. Some aspects of the characterization of decorations on ceramic glazes. Appl. Phys. A 2014, 79, 235-239. [CrossRef] 
16. Pradell, T.; Molina, G.; Molera, J.; Pla, J.; Labrador, A. The use of micro-XRD for the study of glaze color decorations. Appl. Phys. A 2013, 111, 121-127. [CrossRef]

17. Albero Santacreu, D.; Carvajal, J.C.; Mateu Vicens, G. Anàlisi petrològica preliminar de la ceràmica islàmica del Puig de sa Morisca (Calvià, Mallorca). In VII Jornades d'Arqueologia de les Illes Balears; Anglada, M., Riera, M., Martínez, A., Eds.; Consell Insular de Menorca: Maó, Spain, 2017; pp. 301-310.

18. Molera, J.; Pradell, T.; Salvadó, N.; Vendrell-Saz, M. Interactions between clay bodies and lead glazes. J. Am. Ceram. Soc. 2001, 84, 1120-1128. [CrossRef]

19. Albero Santacreu, D.; Calderón, M.; Calvo, M.; Gloaguen, E. Calvià y la conquista cristiana de Jaume I (1229). In Patrimonio Cultural de Calvià (Vol. I); Calvo, M., Aguareles, A., Eds.; Ajuntament de Calvià, Mallorca: Calvià, Spain, 2011; pp. 177-186.

20. Albero Santacreu, D. Primeras aproximaciones a la organización del espacio rural durante época islámica (902-1229) en Qalbiyăn (SO de Mallorca). Arqueología y Territorio Medieval 2011, 18, 145-167. [CrossRef]

21. Malpica, A.; García Porras, A.; Álvarez, J.J.; Carta, R.; Carvajal, J.C.; Bonet, M.T.; Reyes, E. Planteamientos sobre las cerámicas urbanas y rurales del territorio granadino. In La Cerámica en Entornos Urbanos y Rurales en el Mediterráneo Medieval; García Porras, A., Villada, F., Eds.; Museo de Ceuta, Consejería de Educación, Cultura y Mujer: Ceuta, Spain, 2007; pp. 159-290.

22. Ramos, A. Primeres dades sobre la ceràmica andalusina del Puig de sa Morisca (Santa Ponça, Mallorca). In VII Jornades d'Arqueologia de les Illes Balears; Anglada, M., Riera, M., Martínez, A., Eds.; Consell Insular de Menorca: Maó, Spain, 2017; pp. 285-292.

23. Tite, M.; Pradell, T.; Shortland, A. Discovery, production and use of tin-based opacifiers in glasses, enamels and glazes from the late iron age onwards: A reassessment. Archaeometry 2008, 50, 67-84. [CrossRef]

24. Matin, M. Tin-based opacifiers in archaeological glass and ceramic glazes: A review and new perspectives. Archaeol. Anthropol. Sci. 2019, 11, 1155-1169. [CrossRef]

25. Gradmann, R. Analysis of Historical Islamic Glazes and the Development of a Substitution Material. Ph.D. Thesis, Institute of Geography and Geology, Department of Geodynamics and Geomaterial Research, Universität Würzburg, Würzburg, Germany, 2016.

26. Salinas, E.; Pradell, T.; Molera, J. Glaze production at an early Islamic workshop in Al-Andalus. Archaeol. Anthropol. Sci. 2019, 11, 2201-2213. [CrossRef]

27. Milwright, M. An Introduction to Islamic Archaeology; The New Edinburgh Islamic Surveys; Edinburgh University Press: Edinburgh, UK, 2010.

28. Mason, R.B.; Tite, M.S. The beginnings of tin-opacification of pottery glazes. Archaeometry 1997, 39, 41-58. [CrossRef]

29. Molera, J.; Pradell, T.; Salvadó, N.; Vendrell-Saz, M. Evidence of tin oxide recrystallization in opacified lead glazes. J. Am. Ceram. Soc. 1999, 82, 2871-2875. [CrossRef]

30. Tite, M.S.; Freestone, I.; Mason, R.; Molera, J.; Vendrell-Saz, M.; Wood, N. Lead glazes in antiquity. Methods of production and reasons for use. Archaeometry 1998, 40, 241-260. [CrossRef]

31. Vendrell, M.; Molera, J.; Tite, M.S. Optical properties of tin opacified glazes. Archaeometry 2000, 42, 325-340. [CrossRef]

32. Coll, J. Transferencias técnicas en la producción cerámica entre Al-Andalus y los reinos cristianos. El caso de Sharq Al-Andalus. In Cerámicas Islámicas y Cristianas a Finales de la Edad Media. Influencias e Intercambios; Museo de Ceuta, Consejería de Educación, Cultura y Mujer: Ceuta, Spain, 2003; pp. 301-366.

33. Ramos, A.; Albero, D.; Carvajal, J. Estudi tipològic i arqueomètric d'una safa singular recuperada a la Torre III del Puig de sa Morisca (Santa Ponça, Mallorca). In VII Jornades d'Arqueologia de les Illes Balears; Anglada, M., Riera, M., Martínez, A., Eds.; Consell Insular de Menorca: Maó, Spain, 2017; pp. 293-299.

34. Lafuente, P. Pottery and tiles. In The Archaeology of Medieval Spain (1100-1500); Valor, M., Gutiérrez, A., Eds.; Equinox: Sheffield, UK, 2014; p. 82.

35. Coll, J.; García Porras, A. Tipologia, cronologia e produzione dei forni per ceramica in al-Andalus. In Atti XLII Convegno Internazionale della Ceramica. Fornaci: Tecnologie e Produzione della Ceramica in Età Medievale e Moderna; Centro Ligure per la Storia de la Ceramica: Savona, Italy, 2010; pp. 25-44.

36. González Navarro, E. Tradición Tecnológica de la Cerámica de Cocina Almohade-Nazarí; THARG: Granada, Spain, 2008.

37. García Porras, A. Caracterización de una producción cerámica comercializable: La cerámica almohade. In A Ocupação Islâmica da Península Ibérica: Actas do IV Congresso de Arqueologia Peninsular; Ferreira, N., Ed.; Centro de Estudos de Património, Universidade do Algarve: Faro, Portugal, 2008; pp. 139-155.

38. Baldassarri, M.; Berti, G. Nuovi dati sulle importazioni di ceramiche islamiche e bizantine a Pisa. In Actas del VIII Congreso Internacional de Ceramica Medieval; Zozaya, J., Retuerce, M., Hervás, M.A., de Juan, A., Eds.; AEAM: Ciudad Real, Spain, 2009; pp. 63-79.

39. Gutiérrez, J.A.; Valor, M. Housing and domestic life. In The Archaeology of Medieval Spain (1100-1500); Valor, M., Gutiérrez, A., Eds.; Equinox: Sheffield, UK, 2014; pp. 73-99. 